\title{
MODERNISASI PENDIDIKAN ISLAM \\ Landasan Teologis-Filosofis-Historis
}

\author{
Sopian Sinaga, M.Pd.I \\ Program Studi Pendidikan Bahasa Arab STAI As-Sunnah Deli Serdang \\ Jl. Medan-Tg.Morawa, km. 13, Gg.Darmo, Desa Bangun Sari, Kec. Tg.Morawa, \\ Kab. Deli Serdang Sumut \\ abumuhammadsinaga@gmail.com
}

\begin{abstract}
Abstrak: Pendidikan Islam merupakan bagian dari ajaran Islam yang menjadi satu-satunya agama yang dijamin oleh Allah eksistensinya sampai kiamat. Karena itu, sudah sepantasnya pendidikan Islam itu senantiasa relevan untuk dipakai kapanpun dan dimanapun ia berada. Ia harus mampu menjawab permasalahan Zaman, karena itu kita perlu menggali lagi konsep ajaran Islam dalam pendidikan yang relevan dengan perkembangan Zaman, yang demikian ini menunjukkan pentingnya dilakukan modernisasi atau pembaharuan pendidikan Islam. Selain didukung oleh landasan Filosofis, Modernisasi pendidikan Islam juga didukung oleh landasan Teologis dan fakta Historis. Diantara landasannyaadalah hadis yang menyebutkan bahwa Allah akan mengutus untuk umat ini setiap awal seratus tahun orang yang akan memperbaharui untuk mereka agama mereka.Hal ini dikuatkan denganbanyaknya ayat-ayat Alquran yang menyebutkan tentang akal dan perintah penggunaannya yaitu sekitar 49 kali. Dari semua landasan ini, bisa dikatakan bahwa modernisasi pendidikan Islam itu hukumnya wajib, namun harus sesuai dengan syarat dan ketentuan yang telah digariskan oleh para ulama.
\end{abstract}

Kata Kunci : Modernisasi, Pendidikan Islam, Teologis, Filosofis, Historis

\section{Pendahuluan}

Pendidikan Islam adalah usaha yang terencana untuk membentuk peserta didik secara perlahan dan berkesinambungan untuk menggapai kebahagiaan dunia dan akhirat berlandaskan ajaran Islam. Pendidikan Islam memiliki sasaran pengembangan potensi peserta didik dalam bidang keilmuan, pembinaan akidah yang benar, pembinaan ibadah, pembinaan akhlak muliadan profesi hidup serta pembinaan jasmani. ${ }^{1}$ Pendidikan Islam merupakan bagian dari ajaran Islam yang menjadi satu-satunya agama yang dijamin eksistensinya sampai kiamat. Hal ini karena Islam adalah syariat terakhir dari para Nabi dan Rasul yang dibawa oleh Nabi Muhammad saw. Karena pendidikan Islam bersumber kepada Alquran dan Alhadis yang telah

\footnotetext{
${ }^{1}$ Khalid bin Hasan al-Hazimy, Usul at-Tarbiyah al-Islamiyah, (Medinah: Dar al-Alam al-
} Kutub, 1420 H., h. 73. 
dijamin oleh Allah bahwa keduanya akan dijaga oleh Allah sebagaimana

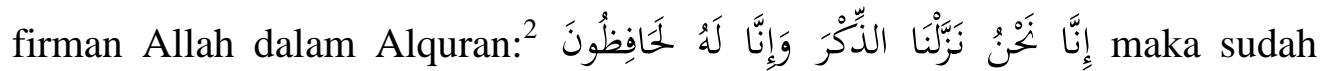
sepantasnya pendidikan Islam itu senantiasa relevan untuk dipakai kapanpun dan dimanapun kita berada. Ketika pendidikan Islam tidak mampu menjawab permasalahan Zaman, maka berarti kita perlu menggali lagi konsep ajaran Islam dalam pendidikan yang relevan dengan perkembangan Zaman, karena itulah perlu dilakukan modernisasi atau pembaharuan pendidikan Islam.

\section{Pembahasan}

\section{Pengertian Modernisasi Pendidikan Islam}

Menurut KBBI, modernisasi berasal dari kata modern yang berarti: 1)terbaru, mutakhir. 2)sikap dan cara berpikir serta sesuai dengan perkembangan zaman. Kemudian mendapat imbuhan sasi menjadi modernisasi sehingga mempunyai pengertian suatu proses pergeseran sikap dan mentalitas sebagai warga masyarakat untuk bisa hidup sesuai dengan perkembangan zaman. ${ }^{3}$

Kata modernisasi sebenarnya adalah berasal dari bahasa Inggris yaitu modernization. ${ }^{4}$ Kata modernisasi bisa diartikan secara bahasa dengan kata pembaharuan, yang dalam bahasa Arab adalah التجديد(atTajdid) dari asal kata جدََّ - يجدد - تجديد. Kata at-tajdid dalam bahasa Arab sering diartikan dalam bahasa Indonesia dengan istilah pembaharuan dan istilah pemurniaan, padahal modernisasi dan pemurniaan itu memiliki perbedaan yang sangat mendasar, karena pembaharuan adalah usaha untuk memperbaharui pemahaman atas aspek-aspek yang masih bersifat relatif terhadap ajaran Islam itu sendiri, sementara pemurniaan adalah usaha untuk meluruskan pemahaman umat Islam terhadap ajaran-ajaran pokok yang sudah bersifat pasti seperti dalam urusan aqidah dan ibadah, sehingga dengan demikian, aqidah dan ibadah bukanlah ranah dan wilayah dari

${ }^{2}$ QS. Al-Hijr: 9.

${ }^{3}$ Departemen Pendidikan dan Kebudayaan, Kamus Besar Bahasa Indonesia, (Jakarta: Balai Pustaka, 1989), h. 589.

${ }^{4}$ Hasan Asari, Modernisasi Islam, Tokoh, Gagasan dan Gerakan (Bandung: Ciptapustaka Media, 2007), h. 1. 
pembaharuan atau modernisasi itu sendiri. ${ }^{5} \mathrm{Hal}$ ini sesuai dengan yang disampaikan oleh Rohadi Abdul Fattah dan Sudarsono, bahwa modernisasi adalah suatu perubahan-perubahan pemikiran, sikap dan watak yang tadinya bersifat tradisional, ke arah pemikiran, sikap dan watak yang bersifat maju. ${ }^{6}$

Busthomi Muhammad Said menyebutkan bahwa Ulama Salaf secara global memaknai kata tajdid (pembaharuan/modernisasi)dengan beberapa uraian, yaitu:

a. Bahwasanya pembaharuan agama adalah menghidupkannya, membangkitkannya dan mengembalikannya kepada aslinya seperti pada masa salaf pertama.

b. Yang termasuk tuntutan tajdid adalah memelihara nash-nash agama yang asli secara benar dan bersih menurut batasan dan ukuran yang telah ditetapkan.

c. Yang termasuk tuntutan tajdid 'pembaharuan' ialah menempuh jalan yang benar dalam memahami nash agama dan memaknakannya dari keterangan yang telah digariskan oleh pola pemikran sunnah (salaf).

d. Tujuan pembaharuan adalah menjadikan hokum agama agar berlaku dan menguasai dimensi-dimensi kehidupan dan segera memperbaiki cara pengamalannya yang salah serta mengembalikan segi-segi yang kurang.

e. Termasuk dalam lingkup tajdid adalah ijtihad, yaitu menganalisa secara islami setiap hal yang baru dan menentukan pandangan Islam pada setiap kejadian. ${ }^{7}$

Adapun arti pendidikan Islam maka ia adalah usaha yang terencana untuk membentuk peserta didik secara bertahap dan berkesinambungan dalam rangka pengembangan potensinya pada semua aspek untuk menggapai kebahagiaan dunia dan akhirat berlandaskan ajaran Islam. Hal ini sebagaimana yang dijelaskan oleh Syekh Khalid Al-

${ }^{5}$ Ibid., h. 3.

${ }^{6}$ Rohadi Abdul Fatah dan Sudarsono, Ilmu, Iman dan Teknologi, (Jakarta: Kalam Mulia,1987), h. 98.

${ }^{7}$ Busthomi Muhammad Said, Pembaharu dan Pembaharuan, (Ponorogo: PSIA, 1992), h. 23. 
Hazimi. ${ }^{8}$ Sementara Azyumardi Azra berpendapat bahwa pendidikan Islam adalah suatu proses pembentukan individu berdasarkan ajaran Islam yang diwahyukan oleh Allah swt. kepada Nabi Muhammad saw.melalui proses dimana individu tersebut dibentuk agar dapat mencapai derjat yang tinggi sehingga mampu melaksanakan tugasnya sebagai khalifah fil ard. ${ }^{9}$ Sedangkan menurut menurut Muhammad 'Athiyah al-Abrasyi memberikan pengertian pendidikan Islam adalah sebuah kegiatan yang hanya memenuhi otak anak didik dengan segala macam ilmu yang belum mereka ketahui, maksudnya ialah mendidik akhlak dan jiwa mereka, menanamkan rasa fadhilah (keutamaan), membiasakan mereka dengan kesopanan yang tinggi, mempersiapkan mereka untuk suatu kehidupan yang suci seluruhnya ikhlas dan jujur. Maka tujuan pokok dan utama dari pendidikan Islam adalah mendidik budi pekerti dan pendidikan jiwa. ${ }^{10}$

Sebelum menjelaskan pengertian modernisasi pendidikan Islam, penulis menyampaikan pengertian modernisasi ajaran Islam. Hal itu karena modernisasi pendidikan Islam adalah bagian dari modernisasi ajaran Islam. Ada beberapa pengertian modernisasi ajaran Islam, namun yang lebih tepat menurut pemakalah adalah ia diartikan sebagai: ${ }^{11}$

تنزيل الاحكام الشرعية على ما يجد من وقائع واحداث ومعالجتها ومعالجة نابعة من هدي الوحي “Menerjemahkan (menurunkan) hukum Islam atas segala permasalahan kontemporer berupa fakta dan peristiwa yang terjadi serta solusi yang tepat yang berasal dari bimbingan wahyu”.

Dari beberapa pengertian di atas, dapat kita simpulkan bahwa modernisasi pendidikan Islam adalahsuatu usaha melakukan perubahanperubahan pemikiran, sikap dan kebijakan dari bersifat tradisional, ke

\footnotetext{
${ }^{8}$ al-Hazimy, Ushul at-Tarbiyah.., h. 73.

9 Azyumardi Azra, Pendidikan Islam; Tradisi dan Modernisasi Menuju Milenium Baru, (Jakarta: Logos Wacana Ilmu, 1999), h. 40.

${ }^{10}$ Muhammad 'Athiyah al-Abrasyi, Dasar-dasar Pokok Pendidikan Islam, (Jakarta: Bulan Bintang, 1987), h. 1.

${ }^{11}$ Adnan Muhammad Umamah, At-Tajdid fi al-Fikri al-Islami, (Dammam: Dar Ibnu alJauzi, 1424H), h. 18.
} 
arah pemikiran, sikap dan watak yang bersifat maju dalam dunia pendidikan yang sejalan dengan ayat-ayat suci dan hadis Nabi saw. demi menjawab segala permasalahan dan kebutuhan zaman.

\section{Landasan Teologis Modernisasi Pendidikan Islam}

\section{a. Ayat-ayat Alquran yang Mendukung Perlunya Pendidikan Modern}

1) Jika kita membaca Alquran, maka kita akan mendapati banyak sekali ayat-ayat yang mendukung perlunya pendidikan modern. Diantaranya adalah banyaknya ayat-ayat Alquran yang menyebutkan tentang akal dan perintah penggunaannya. Syahrin Harahap mengatakan bahwa perintah menggunakan akal dalam Alquran terdapat 49 kali. ${ }^{12}$ Ini menunjukkan bahwa rasionalitas dalam Islam sangat dijunjung tinggi. Ini merupakan salah satu bukti bagaimana Islam menghargai akal dan akal tidaklah dipergnakan kecuali untuk hal positif seperti untuk mengendalikan diri dan mengekang hawa nafsu. ${ }^{13}$

2) Rasulullah saw. adalah tokoh modernisasi di masanya,Allah berfirman: ${ }^{14}$

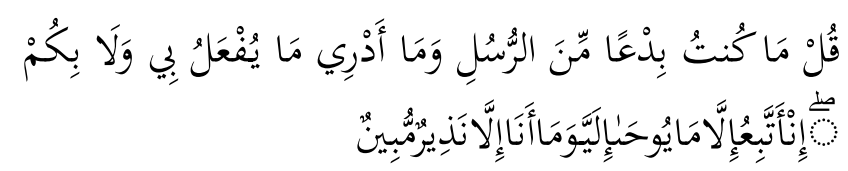

Katakanlah: "Aku bukanlah rasul yang pertama di antara rasulrasul dan aku tidak mengetahui apa yang akan diperbuat terhadapku dan tidak (pula) terhadapmu. Aku tidak lain hanyalah mengikuti apa yang diwahyukan kepadaku dan aku tidak lain hanyalah seorang pemberi peringatan yang menjelaskan".

\footnotetext{
${ }^{12}$ Syahrin Harahap, Islam dan ModernitasDari Teori Modernisasi Hingga Penegakan Kesalehan Modern, (Jakarta: Prenadamedia Group, 2015), h. 18.

${ }^{13}$ Ibid. h. 19.

${ }^{14}$ QS. Al-Ahqaf: 9.
} 
Rasulullah saw. adalah merupakan tokoh modernisasi di masanya. Karena beliau banyak membawa perubahan atas apa yang menjadi kebiasaan kaumnya saat itu. Modernisasi dan perubahan yang beliau bawa di antaranya adalah terkait praktik ibadah, tatacara pembagian warisan, masalah perkawinan, terkait muamalah jual beli dan lain-lain. Perubahan yang beliau bawa ini mendapatkan banyak pertentangan dari kaumnya. Kemudian Rasulullah saw. menjelaskan dengan baik kepada kaumnya bahwa yang beliau ajarkan bukanlah sesuatu yang baru dan aneh sebenarnya, namun hanya meneruskan apa yang diajarkan para Rasul terdahulu. Berdasarkan ayat ini, maka modernisasi pendidikan Islam adalah sesuatu yang baik dan didukung oleh Alquran dan fakta sejarah.

3) Allah mencela orang-orang yang tidak mau menerima perubahan dan pembaharuan atas kebiasaan yang berlaku hanya karena taqlid buta terhadap pendahulu dan leluhur mereka. Allah swt. berfirman tentang mereka pada Alquran: ${ }^{15}$

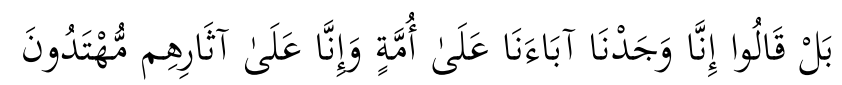

Bahkan mereka berkata: "Sesungguhnya kami mendapati bapakbapak kami menganut suatu agama, dan sesungguhnya kami orang-orang yang mendapat petunjuk dengan (mengikuti) jejak mereka."

Melalui ayat ini, Allah swt. mencela orang-orang dahulu yang mereka tidak mempergunakan akalnya untuk berpikir, justru mereka hanya mengandalkan taqlid dan ikut-ikutan atas amalan dan perbuatan leluhur mereka. Karena inilah kaum musyrikin sulit menerima kebenaran yang dibawa Rasulullah saw. Mereka sulit menerima perubahan disebabkan taqlid buta kepada para leluhur mereka. Taqlid buta kepada leluhur menyebabkan mereka jatuh

${ }^{15}$ QS.Az-Zukhruf: 22 
kepada perbuatan yang paling dimurkai oleh Allah swt. yaitu perbuatan syirik.

Berdasarkan ayat ini, maka modernisasi pendidikan Islam adalah sesuatu yang baik dan didukung oleh Alquran. Yang menolak modernisasi sama dengan menolak perubahan, yang menolak perubahan tanpa alasan yang kuat maka ia mirip dengan sikap kaum Jahiliyah.

4) Perubahan hidup dan kemajuan peradaban manusia harus dimulai dan diupayakan oleh kita umat manusia, bukan menunggu taqdir Allah swt. Allah swt. berfirman: ${ }^{16}$

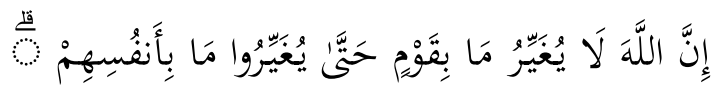

"Allah swt. tidak merubah nasib satu kaum sampai mereka sendiri yang merubahnya"

Ayat ini menjelaskan kepada kita tentang pentingnya melakukan perubahan dalam hidup ini. Perubahan ini perlu dilakukan untuk menggapai kebahagiaan hidup di dunia dan di akhirat. Perubahan itu kita mulai dari diri kita, selanjutnya Allah akan membantu kita dalam melakukan perubahan tersebut insya Allah. Ada beberapa ayat yang semisal ini dalam Alquran di antaranya adalah firman Allah: ${ }^{17}$

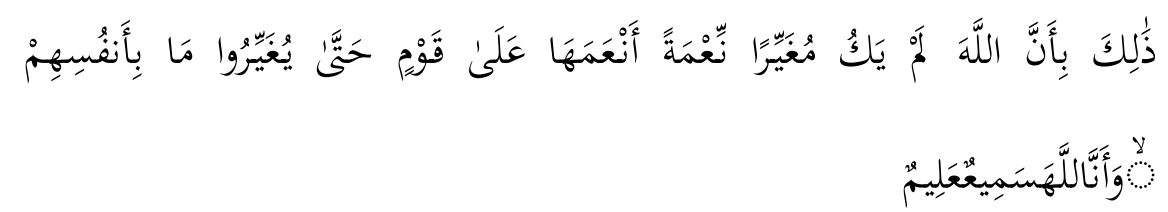

“(Siksaan) yang demikian itu adalah karena sesungguhnya Allah sekali-kali tidak akan meubah sesuatu nikmat yang telah dianugerahkan-Nya kepada suatu kaum, hingga kaum itu merubah apa-apa yang ada pada diri mereka sendiri, dan sesungguhnya Allah Maha Mendengar lagi Maha Mengetahui."

${ }^{16}$ QS. Ar-Ra'd: 11.
${ }^{17}$ QS. Al-Anfal: 53

Jurnal WARAQAT • Volume IV, No. 1, Januari-Juni 2019| 130 
Modernisasi adalah usaha untuk melakukan perubahan ke arah yang ebih baik. Tanpa ada modernisasi atau usaha perubahan untuk lebih baik, maka Allah tidak akan menjadikan kita umat terbaik. Karena semua itu membutuhkan usaha dan kerja keras.

5) Allah menciptakan hidup dan mati untuk menguji kita manakah di antara kita yang terbaik amalannya, Allah berfirman: ${ }^{18}$

$$
\text { الذي خلق الموت والحياة ليبلوكم أيكم أحسن عملا }
$$

"Dialah (Allah) yang telah menciptakan kematian dan kehidupan untuk menguji kalian siapakah diantara kalian yang terbaik amal perbuatannya"

Ibnu Kasir mengatakan yaitu yang terbaik amal perbuatannya sebagaimana dikatakan Muhammad bin Ijlan: Allah tidak mengatakan siapa yang terbanyak amal perbuatannya. ${ }^{19}$

6) Alquran adalah kitab suci yang ajarannya sangat lengkap, menjadi petunjuk dan rahmat serta membawa kabar gembira bagi kaum muslimin, Allah swt. berfirman: ${ }^{20}$

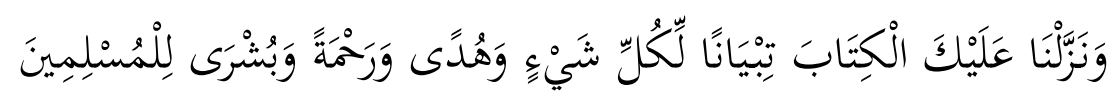

'Dan Kami turunkan kepadamu Al-Kitab (al-Qur'an) untuk menjelaskan segala sesuatu dan petunjuk serta rahmat bagi orangorang yang berserah diri".

Terkait ayat ini Ibnu Mas'ud mengatakan: Allah swt. telah menjelaskan segala sesuatu di dalam Alquran segala ilmu dan segala hal. Sementara Mujahid mengatakan bahwa Allah swt. telah menjelaskan segala yang halal dan haram.PernyataanIbn Mas'ud lebih umum dan lebih menyeluruh, maka sesungguhnya Alquran mencakup semua ilmu yang bermanfaat dari berita yang telah lalu dan ilmu pengetahuan yang akan datang, dan segala yang halal dan haram dan apa saja yang dibutuhkan oleh manusia dalam urusan

\footnotetext{
${ }^{18}$ QS. Al-Mulk: 2.

${ }^{19}$ Ismail Ibn Umar Ibn Kasir al-Quraisyi al-Bashari ad-Dimasyqi, Tafsir Alquran al'Azim, (Beirut: Dar al-Kutub al-'Ilmiyyah, 1998), jilid. VIII, h. 196.

${ }^{20}$ QS. an-Nahl : 89
} 
dunia mereka, agama mereka, kehidupan mereka, akhirat mereka dan menjadi petunjuk bagi hati dan kasih sayang dan kabar gembira bagi kaum muslimin. ${ }^{21}$

7) Para Nabi mengajak untuk melakukan perubahan dan perbaikan tatanan sosial namun mendapat penolakan dari kaumnya, Allah swt. berfirman: ${ }^{22}$

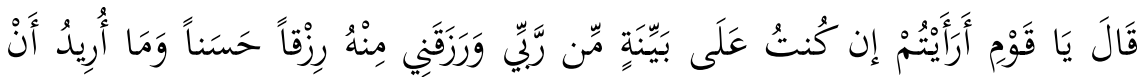

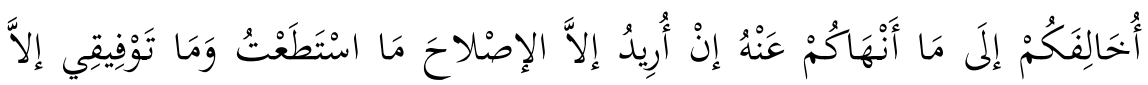
بِاللَّهِ عَلَيْهِ تَوَكَّلْتُ وَإِلَيْهِ أُنِيْبُ

Syu'aib berkata: "Hai kaumku, bagaimana pikiranmu jika aku mempunyai bukti yang nyata dari Tuhanku dan dianugerahi-Nya aku dari pada-Nya rezeki yang baik (patutkah aku menyalahi perintah-Nya)? Dan aku tidak berkehendak menyalahi kamu (dengan mengerjakan) apa yang aku larang. Aku tidak bermaksud kecuali (mendatangkan) perbaikan selama aku masih berkesanggupan. Dan tidak ada taufik bagiku melainkan dengan (pertolongan) Allah. Hanya kepada Allah aku bertawakkal dan hanya kepada-Nya-lah aku kembali."

Perubahan yang diajarkan oleh para Nabi itu tidak lain adalah untuk kebaikan manusia. Selama ada ajakan untuk melakukan perubahan demi kebaikan maka tidak layak untuk ditolak. Karena menolak perubahan yang baik mirip dengan sikap orang-orang Jahiliyah.

8) Islam datang untuk menjadi pemenang bukan pecundang,Allah swt. berfirman: ${ }^{23}$

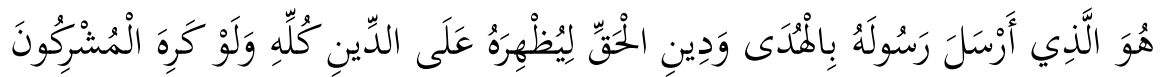

\footnotetext{
${ }^{21}$ Ismail Ibn Umar Ibn Kasir, Tafsir Alquran al- 'Azim ..., jilid. IV, h. 510.

${ }^{22}$ QS. Hud: 88.

${ }^{23}$ QS. At-Taubah: 33.
} 
"Allahlah yang mengutus Rasul-Nya (dengan membawa) petunjuk (al-Qur'an) dan agama yang benar untuk dimenangkan-Nya atas segala agama, walaupun orang-orang musyrik tidak menyukainya".

Islam akan menang dan senantiasa lebih hebat dari ajaran yang lain. Karena itu, maka pendidikan Islam wajib senantiasa berbenah dan meningkatkan mutu dan kualitasnya. Modernisasi pendidikan Islam merupakan usaha perbaikan mutu pendidikan agar senantiasa relevan dengan perkembangan dan kemajuan zaman.

\section{b. Hadis-hadis Nabi yang Mendukung Perlunya Pendidikan Modern}

1) Nabi saw. menyebutkan bahwa setiap 100 tahun Allah akan mengutus pembaharu agama ${ }^{24}$

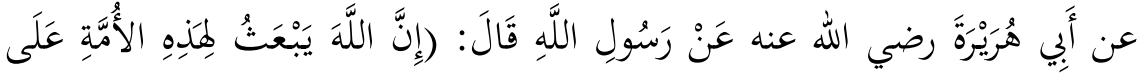

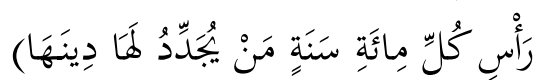

"Dari Abu Hurairah r.a. dari Rasulullah saw. beliau bersbda: Sesungguhnya Allah akan mengutus untuk umat ini setiap awal seratus tahun orang yang akan memperbaharui untuk mereka agama mereka”.

Menurut Syahrin Harahap, hadis ini merupakan isyarat yang jelas mengenai pentingnya pembaharuan dan bangkitnya para pembaharu dalam Islam. $^{25}$

2) Nabi saw. ketika akan mengutus Muadz bin Jabal ke Yaman bertanya: ${ }^{26}$

"Dari Haris bin Amr saudara Mughirah bin Syu'bah dari orangorang negeri Hims yaitu sahabat-sahabat Muadz bin Jabal

\footnotetext{
${ }^{24}$ Abu Daud Sulaiman bin Asy'as bin Ishaq, Sunan Abi Daud, (Beirut: Al-Maktabah AlAsriyah, tt.), jilid IV, h. 109.

${ }^{25}$ Syahrin Harahap, Islam dan Modernitas..., h. 76.

${ }^{26}$ Abu Dawud Sulaiman Ibn al-'Asy’aṡIbn Ishak, Sunan Abi Dawud, (Beirut: alMaktabah al-‘Asriyah, tt.)jilid. III, h. 303.
} 
bahwasanya Rasulullah saw. ketika akan mengutus Muadz bin Jabal ke negeri Yaman beliau berkata: "Bagaimana kamu menyelesaikan satu perkara yang disampaikan kepadamu? Muadz menjawab: Aku akan berhukum dengan hokum yang ada dalam Alquran. Nabi saw. (kembali) bertanya: Bagaimana jika kamu tidak mendapatkannya dalam Alquran? Muadz menjawab: maka aku akan berhukum dengan hukum yang ada dalam Sunnah Nabi saw. nabi kembali bertanya: Bagaimana jika kamu tidak mendapatkan hukumnya dalam Alquran atau Sunnah Nabi? Muadz menjawab: Aku akan berijtihad (berpikir keras) dan tidak akan menyepelekannya. Lantas Nabi menepuk dada Muadz (tanda senang) dan berkata: Segala puji bagi Allah yang telah menunjuki utusan Rasulullah saw. sesuatu yang diridhai Rasulullah saw."

3) Nabi saw. mengakui bahwa urusan dunia itu Nabi tidak lebih mengetahui dari orang lain. Hal itu sebagaimana dijelaskan dalam hadis berikut:

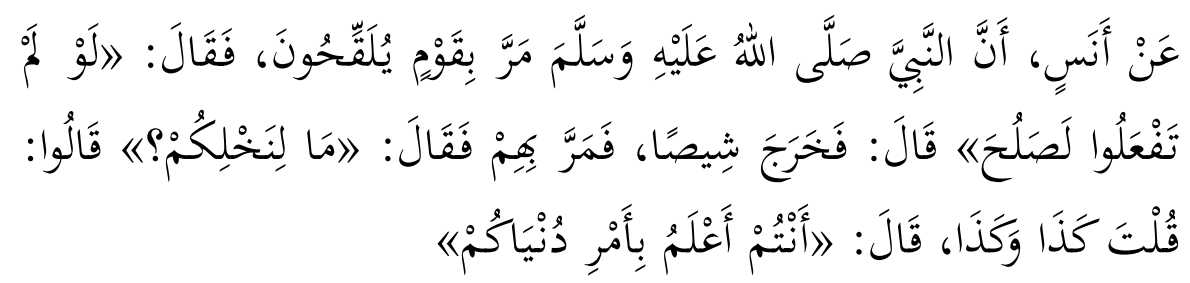

Dari Anas ra: Bahwa Nabi saw. pernah melewati suatu kaum yang sedang mengawinkan pohon kurma lalu beliau bersabda:Sekiranya mereka tidak melakukannya, kurma itu akan (tetap) baik. Tapi setelah itu, ternyata kurma tersebut tumbuh dalam keadaan rusak. Hingga suatu saat Nabi saw. mereka lagi dan melihat hal itu beliau bertanya: Adaapa dengan pohon kurma kalian? Mereka menjawab; Bukankah anda telah mengatakan hal ini dan hal itu? Beliau lalu bersabda: Kalian lebih mengetahui urusan dunia kalian. $^{27}$

${ }^{27}$ Muslim Ibn Hajjaj Abu Hasan al-Qusyairi an-Naisaburi, Sahih Muslim, (Beirut: Dar Ihya at- Turas al-'Arabi), jilid. IV, h. 2074. 
Maksud beliau dengan urusandunia dan kehidupan adalah yang bukan masalah syariat. Adapun perkataan beliau yang berdasarkan ijtihad beliau saw. dan pendapatnya tentang syariatnya maka bagi kita untuk mengamalkannya. Sementara penyerbukan kurma tidaklah termasuk bagian dari syari'at, akan tetapi bagian dari pendapat beliau semata. ${ }^{28}$

4) Nabi saw. memotivasi umatnya untuk berijtihad ${ }^{29}$

"Dari Amr bin Ash bahwasanya beliau telah mendengar Rasulullah saw. bersabda: Jika seorang hakim akan memutuskan satu perkara lalu iapun berijtihad dan ijtihadnya itu benar maka ia akan mendapatkan 2 pahala. Sebaliknya jika ia berijtihad dan hasilnya salah maka ia akan mendapatkan satu pahala”.

Modernisasi terkait erat dengan masalah ijtihad. Ruang berijtihad masih senantiasa terbuka. Menolak modernisasi sama dengan menutup pintu ijtihad. Dalam hadis ini terang sekali bahwasanya Rasulullah saw. memotivasi umatnya untuk berijtihad. Hal itu karena pelaku ijtihad tidak pernah tercela selama ia menggunakan kaedah-kaedah ijtihad yang benar. Pelaku ijtihad senantiasa mulia walaupun ia salah dalam ijtihadnya. Ini jelas merupakan salah satu dalil kuat yang mendukung modernisasi pendidikan Islam.

5) Nabi saw. memotivasi umatnya untuk menjadi orang yang banyak memberi manfaat untuk orang lain. Nabi saw. bersabda:

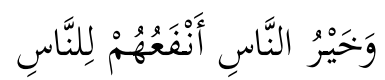

Diriwayatkan dari Jabir berkata,"Rasulullah

Shallallahualaihiwassalam bersabda, 'Orang beriman itu bersikap ramah dan tidak ada kebaikan bagi seorang yang tidak bersikap

${ }^{28}$ Abu Zakaria Muhyiddin Yahya ibn Syaraf An-Nawawi, Al-Minhaj Syarhu Shahih Muslim, cet. 2 (Beirut: Dar Ihyaut Turas Al-'Arabi, 1971), jilid. XV, h. 116.

${ }^{29}$ Muslim Ibn Hajjaj Abu Hasan al-Qusyairi, al-Musnad as-Shahih al-Mukhtasar binaqli al- 'adli ila Rasulullahi Shallallahu 'alaihi wasallam,(Beirut: Dar Ihya at- Turas al-'Arabi, tt.), jilid III, h. 1342. 
ramah. Dan sebaik-baik manusia adalah orang yang paling bermanfaat bagi manusia. ${ }^{30}$

Dengan melakukan pembaharuan atau modernisasi berarti kita telah berupaya untuk mencari satu solusi untuk permasalahan yang dihadapi oleh umat. Usaha itu tentu cukup mulia karena akan memberikan banyak manfaat karena akan dirasakan oleh banyak orang.

\section{Landasan Filosofis Modernisasi Pendidikan Islam}

Perlunya dilakukan modernisasi pendidikan ditinjau dari pertimbangan-pertimbangan rasional setidaknya bisa dilihat dari beberapa hal berikut:

a. Modernisasi identik dengan melakukan ijtihad berusaha untuk mencari alternatif baru guna membeikan solusi atas setiap permasalahan yang ada. Dengan menolak modernisasi seolah kita menutup pintu ijtihad. Jika kaum muslimin menutup pintu ijtihad, niscaya umat akan mengalami kejumudan dan kemandekn berpikir, dan hal ini bertentangan dengan spirit Alquran itu sendiri. ${ }^{31}$

b. Syahrin Harahap berpendapat bahwa signifikasi modernisasi/pembaharuan itu terlihat pada 3 hal: ${ }^{32}$

Pertama, Sesungguhnya Alquran itu mencakup segala hal, dari perkara-perkara dunia sampai perkara akhirat sebagaimana firman Allah swt.

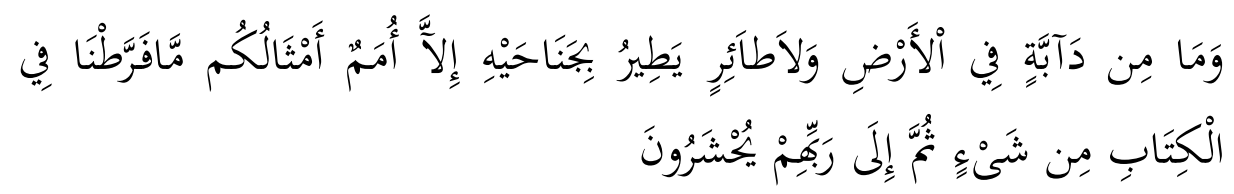

Dan tiadalah binatang-binatang yang ada di bumi dan burung-burung yang terbang dengan kedua sayapnya, melainkan umat-umat (juga)

\footnotetext{
${ }^{30}$ Sulaiman Ibn Ahmad Ibn Ayyub Ibn Mutir al-Lakhmi as-SyamiAbu Qasim atTabrani,al-Mu'zam al-Ausat (Qahirah: Maktabah Ibn Taimiyah, tt.), jilid. VI, h. 58.

${ }^{31}$ John J. Donohue, Islam dan Pembaharuan, (Jakarta: Raja Grafindo Persada, 1993), h. xiii.

${ }^{32}$ Harahap, Islam dan Modernitas...,h. 78.
} 
seperti kamu. Tiadalah Kami apakan sesuatu apapun di dalam AlKitab, kemudian kepada Rabblah mereka dihimpunkan. ${ }^{33}$

Umat Islam meyakini bahwa segala sesuatu yang dibutuhkan oleh manusia dalam hidup dan kehidupannya telah dijelaskan di dalam Alquran berdasarkan ayat di atas, namun kenyataannya Alquran hanya memuat permasalahan agama yang masih bersifat umum, namun dengan keumuman Alquran itu memberikan kesempatan dan peluang kepada manusia khususnya ahli ilmunya untuk memecahkan urusan keduniaannya, sehingga usaha dan upaya pembaharuan dan modernisasi harus terus dilakukan.

Kedua,Sasaran dari modernisasi dan pembaharuan itu adalah pengkajian ulang terhadap ijtihad atau penafsiran ulama pada masa yang lalu terhadap nash-nash Alquran dan Sunnah, karena ijtihad mereka terikat dengan tempat dan waktu ketika mereka menafsirkan nash-nash tersebut, kemudian hasil ijtihad mereka juga masih bersifat relatif, karena ijtihad pada masa lampau terkadang tidak relevan untuk menjawab permasalahan pada zaman modern ini, oleh sebab itu modernisasi atau pembaharuan adalah sebuah kebutuhan dan keharusan.

Ketiga,Pembaharuan itu sesungguhnya bukanlah sesuatu yang baru, karena sesungguhnya Rasulullah saw. telah mengisyaratkan di dalam hadisnya yang mulia. Rasulullah saw. bersabda:

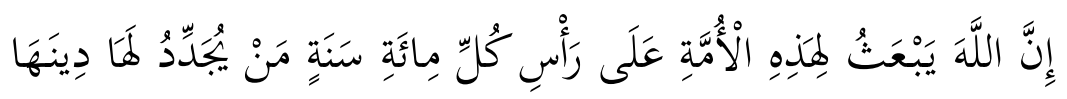

Sesungguhnya Allah akan mengutus (menghadirkan) bagi umat ini (umat Islam) orang yang akan memperbaharui (urusan) agama mereka pada setiap akhir seratus tahun. ${ }^{34}$

c. Azyumardi mengatakan bahwa modernisme pendidikan Islam tidak bisa dipisahkan dengan kebangkitan gagasan dan program modernisme

\footnotetext{
${ }^{33}$ QS. al-An'Am/6:38

${ }^{34}$ Abu Dawud Sulaiman Ibn al-'Asy'aṡIbn Ishak Ibn Basyir Ibn Syaddad Ibn Amr alAzdari as-Sijistani, Sunan Abi Dawud (Beirut: Al- Maktabah Al-‘Asyriyah, tt.), jilid. IV, h. 109.
} 
Islam. Modernisasi pemikiran dan kelembagaan Islam merupakan prasyarat bagi kebangkitan kaum muslimin di masa modern. ${ }^{35}$

d. Pentingnya modernisasi pembaharuan pemikiran Islam itu seperti yang disampaikan Syahrin Harahap terlihat pada lima hal berikut:

1) Modernisasi menawarkan pentingnya pemahaman agama yang lebih rasional dan tidak hanya sekedar mengikuti para pendahulu tanpa Tanya terhadap mereka dalam hal pemahaman agama. Hal ini tentu menyebabkan kejumudan umat Islam sehingga sulit untuk berkembang.

2) Modernisasi dalam Islam menawarkan kesadaran pluralistik (keberagaman pendapat, pemahaman, etnis dan agama) secara tulus.

3) Modernisasi dalam Islam menekankan dengan kuat sekali agar manusia tidak menyerah pada nasibnya, karena manusia memiliki andil yang besar dalam menentukan masa depannya.

4) Modernisasi dalam Islam menekankan penguasaan ilmu pengetahuan dan teknologi dan menganjurkan pengambilan prestasi keilmuan bangsa lain di dunia tanpa dibatasi oleh ras, agama dan Negara.

5) Apa yang dilakukan para penyeru modernisasi dengan perampingan taqlid, pemahaman rasional dan kesadaran pluralistik merupakan upaya untuk meraih kemajuan bersama Alquran dan Hadis. $^{36}$

e. Salah satu karakteristik Pendidikan Islam itu adalah Aś-śabat wal Murunah (Tetap dan Fleksibel). ${ }^{37}$

Dalam ajaran Islam ada kaidah-kaidah umum yang sudah tetap yang tidak bisa dirubah-rubah atau diganti-ganti sepanjang zaman seperti kewajiban menunaikan amanah, kewajiban melaksanakan amar ma'ruf nahi munkar, haramnya mencuri dan berbuat curang,

\footnotetext{
${ }^{35}$ Azyumardi Azra, Pendidikan Islam; Tradisi dan Modernisasi Menuju Milenium Baru, (Jakarta: Logos Wacana Ilmu, 1999), h. 31.

${ }^{36}$ Harahap, Islam dan Modernitas...., h. 79-80.

${ }^{37}$ Khalid al-Hazimi, Ushul at-Tarbiyah al-Islamiyah..., h. 51.
} 
keharaman makan harta riba dan lain-lain. Ini semua tidak menerima perubahan dan pembaharuan hukum. Adapun yang fleksibel maka ia terlihat saat mencari solusi atas satu permasalahan kehidupn yang baru muncul. Tentunya solusi yang ditawarkan adalah merupakan buah dari nilai-nilai ajaran syariat Islam. ${ }^{38}$

f. Menurut Adnan Muhammad Umamah ada beberapa sebab modernisasi perlu dilakukan, yaitu: ${ }^{39}$

1) Karena Islam adalah ajaran yang kekal sampai kiamat

2) Karena ajaran Islam adalah ajaran yang lengkap

g. Karena Islam adalah agama yang layak untuk masa depan

Hal ini karena Islam adalah agama yang diajarkan oleh Nabi Muhammad dan bersumber kepada Alquran. Tidak ada lagi Nabi setelah Nabi Muhammad dan tidak ada lagi kitab suci setelah Alquran. Karena itu, maka ajarannya layak untuk semua umat dan bangsa, layak di manapun dan kapanpun sampai kiamat. Hal ini sejalan dengan George Bernand Shaw dalam Syahrin Harahap, Islam dan Modernitas, yang berpendapat bahwa hanya agama Islamlah satu-satunya agama yang memiliki kepastian untuk berasimilasi terhadap perubahan tahap eksistensi manusia, yang membuatnya tetap memiliki daya tarik yang kuat dalam setiap abad. ${ }^{40}$

h. Karena modernisasi pendidikan Islam termasukMaslahah Mursalahdalam Islam.

Maslahah Mursalah adalah maslahat-maslahat yang bersesuaian dengan tujuan-tujuan syariat Islam, dan tidak ditopang oleh sumber dalil yang khusus, baik bersifat melegitimasi atau membatalkan maslahat tersebut. ${ }^{41}$ Kaitan Maslahah Mursalah dengan Modernisasi Pendidikan Islam adalah karena modernisasi merupakan

\footnotetext{
${ }^{38}$ Ali bin Nayif asy-Syuhud, Al-Khalasah fi Usul at-Tarbiyah al-Islamiyah, (Pahang: Dar al-Makmur, 2009), h. 62.

${ }^{39}$ Khalid al-Hazimi, Usul at-Tarbiyah al-Islamiyah...., h. 21.

${ }^{40}$ Syahrin Harahap, Islam dan Modernitas...., h. XV.

${ }^{41}$ Romli, Muqaranah Mazahib fil Ushul, Cet I . (Jakarta: Gaya MediaPratama, 1999), h. 162 .
} 
usaha untuk meningkatkan mutu dan kualitas pendidikan yang berusaha menyesuaikan dan menterjemahkan antara dalil agama dengan kebutuhan dan kondisi sosial masyarakat. Sementara Maslahah Mursalah adalah suatu hal yang dibutuhkan masyarakat yang tidak ada perintahnya secara jelas dalam Alquran maupun dalam Hadis. Berdasarkan kriteria tersebut maka modernisasi pendidikan Islam merupakan bagian dari Maslahah Mursalah.

i. Fiqh Islam itu berkembang.

Karena Islam adalah agama yang diturunkan untuk seluruh umat manusia sampai kiamat, maka fiqh dalam Islam dituntut untuk dapat menjawab segala permasalahan yang dihadapi oleh umat. Dalam praktiknya, fiqh yang dilahirkan dari ilmu Ushul Fiqh telah mampu memberikan jawaban atas segala permasalahan kontemporer yang dikenal dengan Fiqh Kontemporer.

\section{Landasan Historis Modernisasi Pendidikan Islam}

Fakta sejarah telah membuktikan bahwa ilmu fiqh dan hukum Islam itu berkembang dan tidak jumud. Karena itulah walaupun Imam Syafii berguru kepada Imam Malik, namun beliau tidak mencukupkan apa yang beliau dapat dari gurunya. Imam Syafii mengembangkan keilmuan yang beliau dapatkan dari Imam Malik sehingga beliau memiliki madzhab tersendiri dari gurunya. Begitu juga Imam Ahmad, beliau telah berguru kepada Imam Syafii, namun beliau juga tidak mencukupkan atas apa yang sudah diajarkan gurunya yaitu imam Syafii. Imam Ahmad mengembangkan keilmuan yang beliau dapatkan sehingga beliau juga memiliki madzhab tersendiri yang berbeda dengan gurunya. Ini menunjukkan adanya perkembangan ilmu fiqh dari waktu ke waktu. Juga menunjukkan kebolehan berijtihad dan memperbaharui tradisi keilmuan yang sudah ada. Pembaharuan atas tradisi keilmuan yang ada tidak menimbulkan perpecahan di kalangan ulama bahkan di kalangan umat.Dari sini, kita menyadari bahwa 
pendidikan Islam itu berkembang dan tidak jumud. Jika pendidikan Islam itu tidak berkembang, maka akan sulit kita untuk menerima halhal baru yang terjadi di masyarakat. Sekarang banyak sekali hal-hal baru yang tidak ada di masa ulama klasik seperti hukum shalat di atas pesawat, masalah bayi tabung, masalah ber-KB dan alat kontrasepsi, transplantasi organ manusia dan lain-lain. ${ }^{42}$

Sejarah telah menunjukkan adanya perubahan dan pembaharuan dalam hal hukum dan sumbernya. Karena itulah maka dikenal dalam studi Islam satu disiplin ilmu yang disebut dengan Tarikh at-Tasyri' atau Tarikh al-Figh. Ia adalah satu ilmu yang membahas perkembangan ilmu fiqh dan hukum Islam dari masa Rasulullah saw. sampai masa sekarang, mazhab para ahli fiqh dan kaedah-kaedah setiap mazhab. ${ }^{43}$

\section{Penutup}

Sebagai kesimpulan atas makalah sederhana ini adalah bahwa modernisasi pendidikan Islam itu mutlak penting dilakukan. Bahkan dapat dikatakan bahwa modernisasi pendidikan Islam itu hukumnya wajib. Hal itu didukung oleh landasan teologis dan landasan filosofis serta fakta historis. Diantara bukti wajibnya modernisasi pendidikan Islam adalah bahwa kehidupan manusia itu terus mengalami perubahan dan perkembangan. Perubahan tersebut menuntut kita untuk dapat beradaptasi dengannya, kalau tidak maka kita akan menghadapi banyak masalah. Untuk mengikuti perubahan tersebut, maka mutlak inovasi dan modernisasi pendidikan dilakukan.Modernisasi pendidikan Islam itu memiliki objek khusus dan kaedah-kaedah tertentu yang hanya dengan itulah modernisasi pendidikan Islam itu dapat dilakukan dan akan menghasilkan banyak gagasan baru yang sejalan dengan spirit Alquran dan Hadis serta Ulama masa keemasan dahulu.

\footnotetext{
${ }^{42}$ Amir al-Hafi, Tajdid al-Fikri al-Islami, (Ceramah dari You Tube : https: //www.youtube.com /watch?v= nXV-hPs7fkU)

${ }^{43}$ Manna' al-Qattan, Tarikh at-Tasyri' al-Islami, (tt : Maktabah Wahbah, 2001), h. 5.
} 


\section{Pustaka Acuan}

Alquranal-Karim

al-Abrasyi, Muhammad 'Athiyah, Dasar-dasar Pokok Pendidikan Islam, Jakarta: Bulan Bintang, 1987

al-Bukari, Muhammad Ibn Isma'il Abu Abdillah, al-Jami' al-Musnad as-Shahih al-Mukhtasar min Umuri Rasulullah Shallallahu 'Alaihi Wasallam wa Sunanih wa Ayyamihi, cet. 2, Riyad: Dar Tuqun Najah, 2002.

al-Hazimy, Khalid bin Hasan, Usul at-Tarbiyah al-Islamiyah, (Medinah: Dar alAlam al-Kutub, $1420 \mathrm{H}$

al-Maraghi, Ahmad Ibn Mustafa, Tafsir al-Maraghi, Mesir: Mustafa al-Babi alHalabi, 1946.

an-Nawawi Abu Zakaria Muhyiddin Yahya ibn Syaraf , al-Minhaj Syarhu Shahih Muslim, cet. 2, Beirut: Dar Ihyaut Turas Al-'Arabi, 1971.

al-Quraisyi, Ismail ibn Umar ibn Kasir, Tafsir Alquranil 'azim, Beirut: Dar alKutub al-'Ilmiyyah, 1998.

al-Qattan, Manna', Tarikh at-Tasyri' al-Islami, tt : Maktabah Wahbah, 2001

al-Qusyairi, Muslim Ibn Hajjaj Abu Hasan, al-Musnad as-Shahih al-Mukhtasar binaqli al-'adli ila Rasulullahi Shallallahu 'alaihi wasallam, Beirut: Dar Ihya at- Turas al-'Arabi, tt.

asy-Syuhud, Ali bin Nayif, Al-Khalasah fi Usul at-Tarbiyah al-Islamiyah, Pahang: Dar al-Makmur, 2009

Asari, Hasan, Modernisasi Islam, Tokoh, Gagasan dan Gerakan, Bandung: Ciptapustaka Media, 2007.

as-Sijistani, Abu Dawud Sulaiman Ibn al-'Asy'aṡ Ibn Ishak ibn Basyir Ibn Syaddad ibn Amr al-Azdari, Sunan Abi Dawud, Beirut: al- Maktabah al'Asriyah, tt.

at-Tabrani, Sulaiman Ibn Ahmad Ibn Ayyub Ibn Mutir al-Lakhmi as-Syami Abu Qasim, al-Mu'zam al-AusatQahirah: Maktabah Ibn Taimiyah, tt

Azra, Azyumardi, Pendidikan Islam Tradisi dan Modernisasi Menuju Milenium Baru, Jakarta: Logos Wacana Ilmu, 1999.

Departemen Pendidikan dan Kebudayaan, Kamus Besar Bahasa Indonesia, Jakarta: Balai Pustaka, 1989

Donohue, John J., Islam dan Pembaharuan, Jakarta: Raja Grafindo Persada, 1993

Fatah, Rohadi Abdul dan Sudarsono, Ilmu, Iman dan Teknologi, Jakarta: Kalam Mulia,1987

Harahap, Syahrin, Islam dan Modernitas Dari Teori Modernisasi Hingga Penegakan Kesalehan Modern, Jakarta: Prenadamedia Group, 2015.

Romli, Muqaranah Mazahib fil Ushul, Jakarta: Gaya MediaPratama, 1999

Said, Busthomi Muhammad, Pembaharu dan Pembaharuan, Ponorogo: PSIA, 1992 